\title{
Indirect effects of protection from exploitation: patterns from populations of Evechinus chloroticus (Echinoidea) in northeastern New Zealand
}

\author{
Russell G. Cole*, Dominic Keuskamp** \\ Leigh Marine Laboratory, University of Auckland, PO Box 349, Warkworth, New Zealand
}

\begin{abstract}
The influence of predators on populations of the sea urchin Evechinus chloroticus in northeastern New Zealand was investigated by comparing densities, population size structure, and crevice occupancy in marine reserve ('protected') and exploited locality pairs. There was no overall difference in sea urchin density between protected and exploited localities, but population size structures were generally more bimodal in the protected localities. Size-related patterns of crevice occupancy did not vary consistently between protected and exploited locality pairs. The effects of protection were most pronounced in the Cape Rodney - Okakari Point (CROP) Marine Reserve, where relative to the adjacent fished area (1) sea urchin densities were $\sim 3$ times lower, (2) size structures were more bimodal, and (3) sea urchins remained crevice-bound to larger sizes ( $\sim 40 \mathrm{~mm}$ test diameter). Sea urchin transplant experiments showed higher losses of 30 to $40 \mathrm{~mm}$ test diameter $E$. choroticus at a protected locality than a fished locality. Tests of adult sea urchins were heavier at sites in the reserve relative to the fished reference area. We suggest that predatory fishes, which were larger and more numerous in the reserve, were the cause of the differences. A strong bimodal size structure persisted and density declined over 10 yr at one site in CROP Marine Reserve. We suggest that generalising from reserve studies to exploited areas may lead to erroneous conclusions.
\end{abstract}

KEY WORDS: Echinoid · Marine reserve Predation $\cdot$ Refuge $\cdot$ Carnivorous fishes · Grazing

\section{INTRODUCTION}

Sea urchins are influential benthic grazers in shallow temperate reef systems. Dense populations of these echinoids create and maintain areas devoid of brown macroalgae and dominated by coralline algae (reviewed by Lawrence 1975, Lawrence \& Sammarco 1982, Schiel \& Foster 1986). As a consequence, the factors that regulate sea urchin populations have been widely studied. The roles that predators of sea urchins play in altering reef habitat structure have been the topic of considerable debate (e.g. Miller 1985, Foster \& Schiel 1988, Aronson 1990, Elner \& Vadas 1990,

\footnotetext{
- Present address and address for correspondence: NIWA, PO Box 893, Nelson, New Zealand.

E-mail: r.cole@niwa.cri.nz

- Present address: School of Biological Sciences, Flinders University of South Australia, GPO Box 2100, Adelaide SA 5001, Australia
}

Scheibling 1996). In the northeastern Pacific sea otter predation has been shown to have a major effect on populations of sea urchins, and ultimately on assemblage structure (Estes et al. 1978, Breen et al. 1982, Estes \& Duggins 1995). Similar top-down control of echinoids by fishes on tropical reefs can cause marked community-level habitat changes (e.g. McClanahan et al. 1996). However, clear empirical evidence to support a similar role for predation by non-mammalian predators on subtidal temperate reefs does not yet exist (reviewed by Harrold \& Pearse 1987, Scheibling 1996).

Localised aggregations of sea urchins ('feeding fronts') may alter habitat boundaries by intensively grazing areas (Foreman 1977, Schiel 1982, see review by Harrold \& Pearse 1987), while behavioural changes may be sufficient to alter grazing intensity in other systems (Ebling et al. 1966, Dean et al. 1984, Ebeling et al. 1985, Harrold \& Reed 1985). Storms may directly kill exposed sea urchins (Cowen et al. 1982, Harris et 
al. 1984, Ebeling et al. 1985, Lawrence 1996) and/or alter supply of drift algae (Ebeling et al. 1985, Harrold \& Reed 1985). Both mechanisms can restrict sea urchins to refugia and reduce grazing pressure (preceding references). A relationship between predators, sea urchin behaviour and grazing pressure postulated in Nova Scotia (e.g. Bernstein et al. 1981, 1983, Mann et al. 1984) was later criticised by Vadas et al. (1986). The nature of predator effects on sea urchin behaviour remains unclear (Scheibling 1996)

In addition to exhibiting behavioural variability, regular echinoids are phenotypically plastic (see review of Ebert 1996). Some species have a relatively larger feeding apparatus (Aristotle's lantern) where food is limited (e.g. Ebert 1980, Black et al. 1982, Levitan 1991, McShane \& Anderson 1997). Levitan (1992) used museum collections of echinoid tests and jaws to address long-term change in food availability. Levitan (1991) concluded that in a diadematid urchin the test shrank around the jaws, thus increasing the relative size of the feeding apparatus (see Constable 1993). Different echinoid taxa express these changes differently, with the Diadematidae changing test size more rapidly than other families (Levitan 1991).

The endemic echinometrid Evechinus chloroticus is the dominant grazer on shallow northeastern New Zealand reefs (Andrew 1988) and at sufficient density maintains areas of 'coralline flats' at $\sim 5$ to $10 \mathrm{~m}$ depth (Ayling 1981, Andrew \& Choat 1982, Choat \& Schiel 1982). This habitat is defined by the absence of large brown macroalgae and presence of crustose coralline algae (Ayling 1978, Andrew \& Choat 1982), but also supports abundant fish predators of $E$. chloroticus (Choat \& Ayling 1987). Palinurid lobsters are abundant in macroalgal stands inshore and offshore of the coralline flats habitat (MacDiarmid 1991), but they are thought to have minimal impact on E. chloroticus populations on coralline flats (Andrew \& Choat 1982, Andrew \& MacDiarmid 1991). Coralline flats have persisted for decades at one well-studied site, where Andrew \& Choat (1982) enhanced survivorship of juvenile echinoids by excluding predators. They suggested that although present densities of fishes were insufficient to alter habitat distribution, fish predation may have been responsible for bimodal size structures of E. chloroticus on coralline flats.

Most studies of Evechinus chloroticus in northeastern New Zealand were conducted in the Cape Rodney to Okakari Point (CROP) Marine Reserve, which has been protected from exploitation since 1975 (Ballantine 1991). This is one of several areas in New Zealand protected by 'Marine Reserve' or 'Marine Park' status (Creese \& Cole 1995). They vary in spatial extent and have been protected for varying periods, but there is increasing evidence that abundances of exploited organisms, including predators of sea urchins, are higher in protected areas than in adjacent fished areas (McCormick \& Choat 1987, Cole et al. 1990, MacDiarmid \& Breen 1993). In many of the studies that detected effects of predators on sea urchin populations, human exploitation of these predators ultimately determined predation intensity (e.g. Breen \& Mann 1976, Bernstein et al. 1981, Mann 1982, Tegner \& Levin 1983). Manipulating large, mobile predators on spatially and temporally relevant scales remains impractical (Estes 1995). However, areas protected from human exploitation have recently been used to assess the influence of predation on sea urchin populations (e.g. Sala \& Zabala 1996).

To investigate the influence of variation in fish predator density on populations of Evechinus chloroticus, we examined the density, size structure, and shelter occupancy of sea urchin populations among several localities in northeastern New Zealand including the 3 longest-established marine protected areas (MPAs) in the country. In addition, sea urchin morphological characteristics and predator abundance and size structure were compared between fished and protected localities at Leigh. Survivorship of small $E$. chloroticus transplanted among sites in those localities was compared. Long-term measurements of sea urchin population parameters were made at one well-studied site in CROP Marine Reserve.

\section{METHODS}

Sea urchin density, size structure and crevice occupancy. Evechinus chloroticus populations were sampled for density, population size structure, and crevice occupancy by SCUBA diving at 6 localities in northeastern New Zealand. Four coastal localities were sampled: Tawharanui Marine Park (protected) and eastern Kawau Island (fished) in 1996, CROP Marine Reserve (protected) and Coastal Leigh (fished) in 1997 (Fig. 1). Size and crevice occupancy data from Poor Knights Is. Marine Reserve (protected, and sampled in 1992) are also presented and compared with data from the Mokohinau Is. (fished, sampled in 1996) (Fig. 1). Choat \& Ayling (1987) recorded similarities in the fish faunas of those offshore island groups. Five sites on coralline flats (depth 5 to $10 \mathrm{~m}$ ) were sampled at all localities except at offshore islands, where logistics restricted sampling to 4 sites. All sea urchins in $1 . \mathrm{m}^{2}$ quadrats ( $n=20$ ) were counted and at least 60 individuals were measured while diving at each site (more than 400 were measured for each locality). Measurements of test diameter (TD) were made to $1 \mathrm{~mm}$ with vernier calipers. Although we have measured $E$. chloroticus as small as $3 \mathrm{~mm}$ TD during sampling, and 


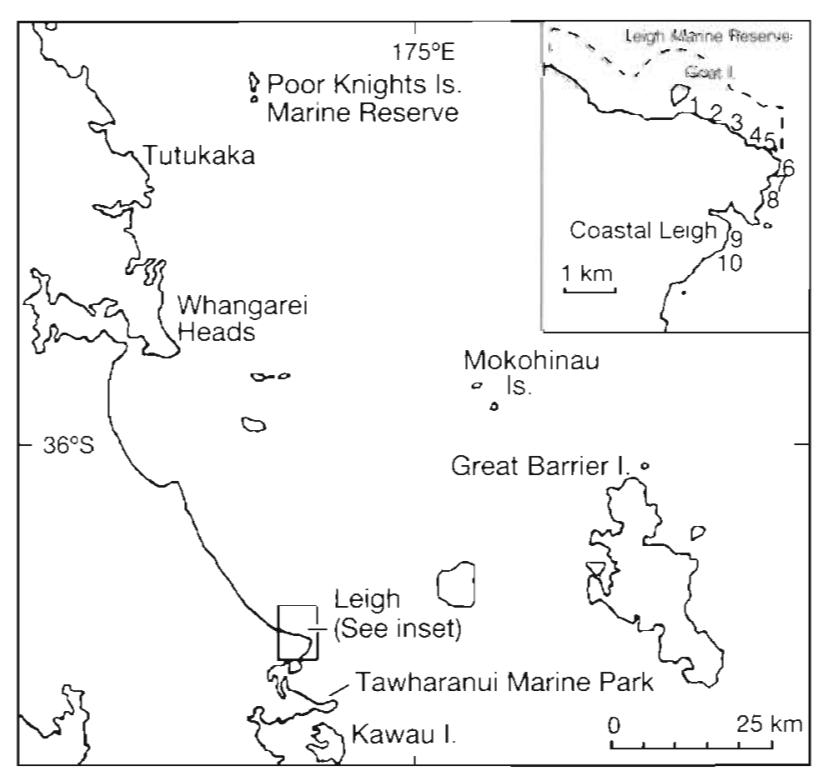

Fig. 1. Location of sampling localities on the northeastern coast of New Zealand. Numbers indicate sites sampled at Leigh. In CROP Marine Reserve: 1 = Waterfall Reef, $2=$ Tower Rock, 3 = Tabletop, 4 = Onespot, $5=$ Rodney Cove; at Coastal Leigh: $6=$ Rodney South, $7=$ Drift Bay, $8=$ Vee Bay, $9=$ Nordic and $10=$ Penguin St.

regularly found $5 \mathrm{~mm}$ TD E. chloroticus at monitoring sites, we are confident that animals larger than $10 \mathrm{~mm}$ TD were quantitatively sampled. For each individual measured in quadrats, we also recorded whether or not it occupied a crevice. Densities of 'exposed' E. chloroticus (those not occupying crevices) were analysed. Where it was impossible to remove small individuals without crushing them, their test diameters were estimated to $5 \mathrm{~mm}$ by holding the scale of the calipers next to the urchin. Keuskamp (1997) showed marked differences in population size structure of E. chloroticus between sandstone and greywacke reefs (western and eastern areas of the CROP reserve respectively) so we concentrated on eastern reefs, which have the same rock type as those at Coastal Leigh.

One site in CROP Marine Reserve, Waterfall Reef, was sampled repeatedly for density (1988 to 1997 , 28 measures), size structure and crevice occupancy (1990 to 1997, 26 measures) using the method described above.

Sea urchin morphometry. We compared structural characteristics of Evechinus chloroticus in protected and unprotected areas near Leigh, to ascertain whether differences existed between localities in lantern size and test weight. Ten E. chloroticus in the size range 55 to $65 \mathrm{~mm}$ TD were collected from coralline flats habitat at each of the 5 sites at CROP Marine Reserve and Coastal Leigh to examine morphometry. The sea urchins were returned to the laboratory, where TD was measured to $1 \mathrm{~mm}$, and following dissection, wet weight of the test (with lantern and viscera removed) was also measured. Following cleaning in $5 \%$ sodium hypochlorite for $48 \mathrm{~h}$ to remove organic material, lengths of 3 haphazardly chosen demipyramids per lantern were measured to $0.1 \mathrm{~mm}$ with vernier calipers according to the method of Levitan (1992).

Sea urchin transplant. Short-term survivorship of small Evechinus chloroticus was compared experimentally at the protected and fished Leigh localities. $E$. chloroticus in the size class 30 to $40 \mathrm{~mm}$ TD were the largest to be consistently crevice-bound at CROP Marine Reserve sites but were commonly found on open substratum at Coastal Leigh (Cole 1993, this study). Sea urchins of this size were therefore transplanted from Coastal Leigh to CROP Marine Reserve. A fully-crossed design, with reciprocal transplants from reserve to fished sites, was impractical, because of low densities of 30 to $40 \mathrm{~mm}$ individuals in the protected area. It is possible that some sea urchins migrated out of the area. Exposed E. chloroticus move in the order of 1 to $2 \mathrm{~m}$ per night in the coralline flats habitat (Andrew \& Stocker 1986), though this information probably pertains to slightly larger individuals.

Four transplant trials were carried out: 2 between Drift Bay (fished) and Waterfall Reef (protected) in April 1997 and 1 from Vee Bay (fished), to each of Onespot and Tower Rock (protected) in August 1997 (see Fig. 1). At each site 2 areas of coralline flats were selected, within which 2 concentric squares of areas 16 and $36 \mathrm{~m}^{2}$ were marked with plastic tags nailed to the substratum. The experimental area was then exhaustively searched for all sea urchins $\sim 30$ to $40 \mathrm{~mm}$ TD, which were collected and removed several hundred metres away. Clearing the area in this manner obviated the need for individual tagging (and assessment of tagging artifacts), which is problematic for this species (Dix 1970b), and only marginally decreased overall density in the plots.

For each transplant, exposed Evechinus chloroticus of 30 to $40 \mathrm{~mm}$ TD were collected from the fished site. measured and (1) transported to the protected site or (2) returned to the source site as controls. Mean test diameter of each group $(n=20)$ ranged from 33 to $38 \mathrm{~mm}$. In each $16 \mathrm{~m}^{2}$ quadrat all 20 individuals were placed in crevices. Sites were revisited each day that weather permitted and the plots were carefully searched for all 30 to $40 \mathrm{~mm}$ sea urchins, noting the number in the central quadrat and the border area (the difference between the 2 allowing some assessment of movement). Experiments were run for at least $4 \mathrm{~d}$ and until further observations were restricted by weather.

Fish density and size structure. In December 1997 populations of predatory fishes were surveyed at 5 sites in CROP Marine Reserve and 5 sites at Coastal 
Leigh (the same ones used in sea urchin population surveys). Potential fish predators of Evechinus chloroticus were counted in $25 \times 5 \mathrm{~m}$ transects ( $\mathrm{n}=10$ ), counted as the tape was laid with a $10 \mathrm{~m}$ lead-in sector, in which fish were not counted (as in Cole et al. 1990, Cole 1994). Eight fish species (Parapercis colias, Pagrus auratus, Cheilodactylus spectabilis, Upeneichthys lineatus, Notolabrus celidotus, Notolabrus fucicola, Chironemus marmoratus, and Parika scaber) were sampled, and their total lengths were estimated in situ. Feeding details and references to autecological studies of those species may be found in Choat \& Ayling (1987), but a priori we identified the first 3 above-named as being of special interest because they were more abundant and larger in the reserve (McCormick \& Choat 1987 , Cole et al. 1990).

\section{RESULTS}

\section{Sea urchin density, size structure and crevice occupancy}

There was no clear overall difference in density of exposed Evechinus chloroticus between protected and fished localities (Fig. 2). Densities were on average 3 times higher at Coastal Leigh sites relative to CROP Marine Reserve, but were similar among Kawau I. and Tawharanui sites. Greatest densities were recorded from Coastal Leigh sites, and the least abundant populations were found in CROP Marine Reserve. Densities of $E$. chloroticus varied markedly among sites within localities, with densities at Coastal Leigh and CROP Marine Reserve sites being more similar than at other localities.

The sizes of Evechinus chloroticus measured in the 6 localities ranged from 3 to $112 \mathrm{~mm}$. Maximal sizes were $>100 \mathrm{~mm}$ at offshore island localities and $>85 \mathrm{~mm}$ on the coast, except at Coastal Leigh, where the largest Evechinus measured was $76 \mathrm{~mm}$. Size structures were consistently more bimodal and had lower proportions of exposed individuals at protected than at fished localities (Fig. 3). These contrasts were most distinct at the Leigh localities, where the Coastal Leigh modal size class corresponded to the trough in the CROP Marine Reserve size structure. Size structures at Coastal Leigh and Kawau I. were similar, but there was a slightly higher representation of the smaller size classes at Coastal Leigh.

Size-related patterns of shelter occupancy differed inconsistently between protected and fished localities (Fig. 4)

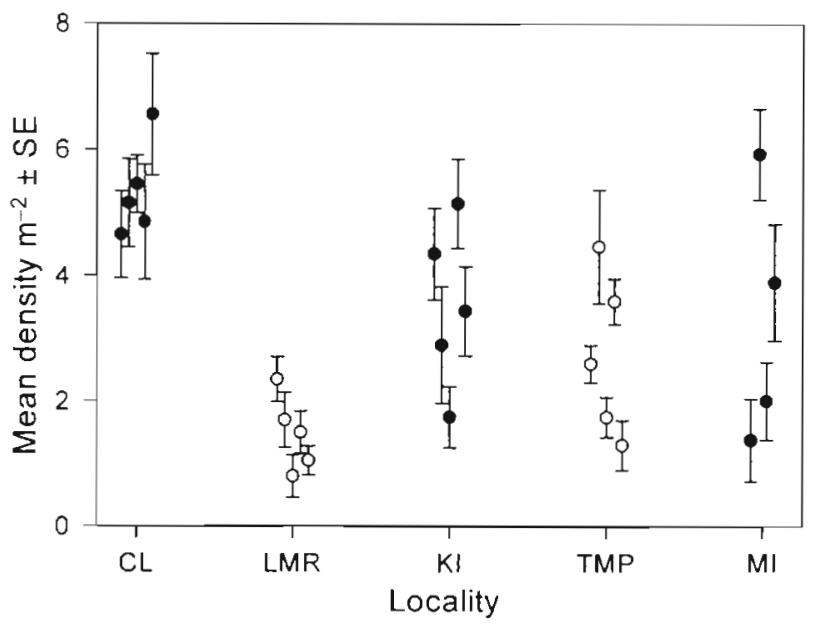

Fig. 2. Evechinus chloroticus. Densities of exposed individuals at protected $(0)$ and fished $(\bullet)$ localities in northeastern New Zealand, measured in $1 \mathrm{~m}^{2}$ quadrats $(\mathrm{n}=20)$. Localities are: $\mathrm{CL}=$ Coastal Leigh, $\mathrm{LMR}=\mathrm{CROP}$ Marine Reserve, $\mathrm{KI}=$ Kawau Island, TMP = Tawharanui Marine Park, MI = Mokohinau Islands. Five sites sampled at all localities, except MI, where 4 sites were sampled. See Fig. 1 for locations

Evechinus chloroticus occupied crevices to $\sim 20 \mathrm{~mm}$ larger TD in CROP Marine Reserve than at Coastal Leigh. Crevice occupancy was closely matched at Tawharanui and Kawau I. At the protected Poor Knights Is., E. chloroticus were found exposed on the substratum at $\sim 10 \mathrm{~mm}$ smaller than those at Mokohinau Is. (the opposite pattern to that at Leigh localities). Sea urchins at the offshore island groups were crevicebound at larger sizes than those at coastal localities.

\section{Waterfall Reef}

There was a general trend of decreasing density at Waterfall Reef through time, from $-4 \mathrm{~m}^{-2}$ in 1988 to
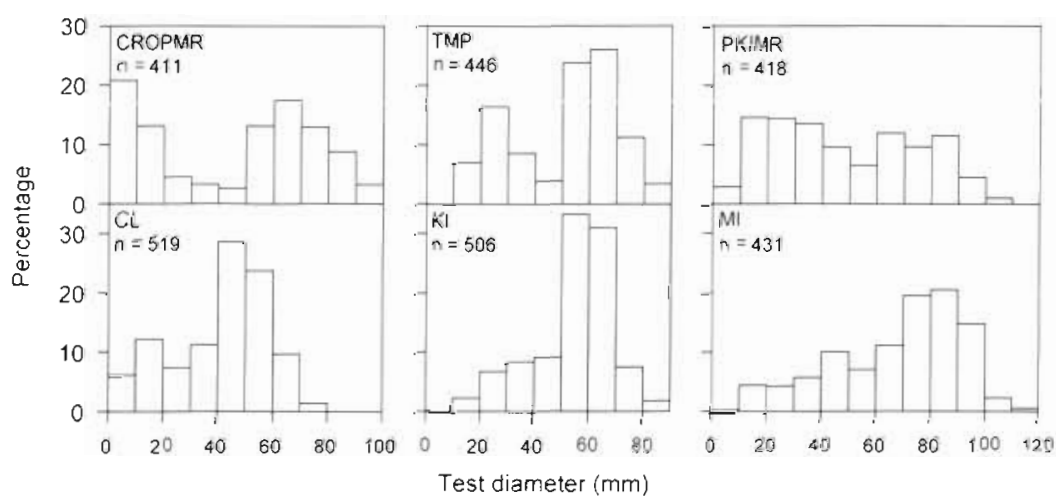

Fig. 3. Evechinus chloroticus. Population size structures at protected (upper panels) and fished (lower panels) localities. PKIMR $=$ Poor Knights Is. Marine Reserve; other abbreviations for localities in Fig. 2 legend 


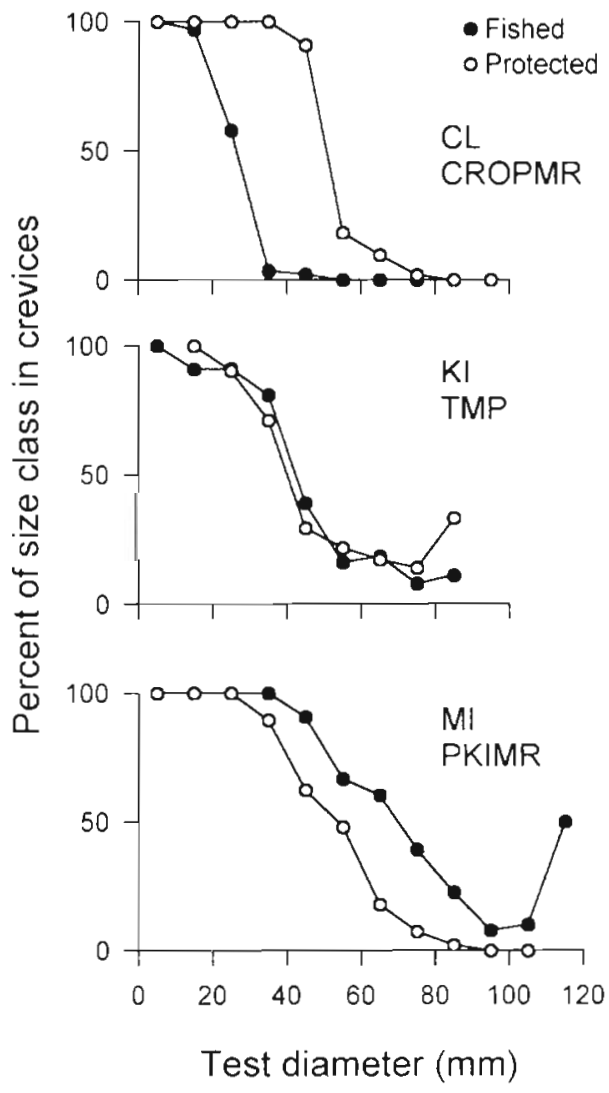

Fig. 4. Evechinus chloroticus. Percentage of size classes accupying crevices in protected and fished localities. PKIMR = Poor Knights Is Marine Reserve; other abbreviations for localities in Fig. 2 legend. Sample sizes as in Fig. 3

$\sim 1 \mathrm{~m}^{-2}$ in 1997 (Fig. 5). However, the decline through that period was similar in magnitude to the variation among samples within a single day. The size structure of the Waterfall Reef Evechinus chloroticus population was remarkably stable from 1990 to 1997 and strongly bimodal, with a persistently low proportion of 30 to

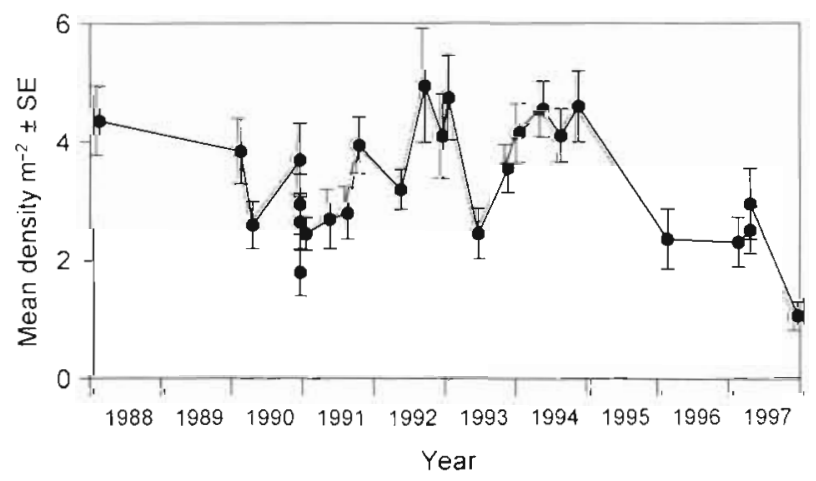

Fig. 5. Evechinus chloroticus. Density at Waterfall Reef coralline flats. CROP Manne Reserve, 1988-1997 measured by $1 \mathrm{~m}^{2}$ quadrats, $\mathrm{n}=20$
$50 \mathrm{~mm}$ individuals (Fig. 6). (Only 12 of the 28 samples, at approximately 8 mo intervals, are shown here for clarity). The position of the upper mode of 60 to $70 \mathrm{~mm}$ did not change, whereas recruitment (measured by the appearance of the smallest size classes) was seasonally recurrent but fluctuated in intensity among years. The size-related pattern of shelter occupancy was also consistent through time: over $90 \%$ of all E. chloroticus $<40 \mathrm{~mm}$ sampled at Waterfall Reef were crevicebound from 1990 to 1997.

\section{Sea urchin morphometry}

Test weight was consistently greater for sea urchins from CROP Marine Reserve than for Coastal Leigh, but jaw length did not vary systematically with reserve status (Table 1).
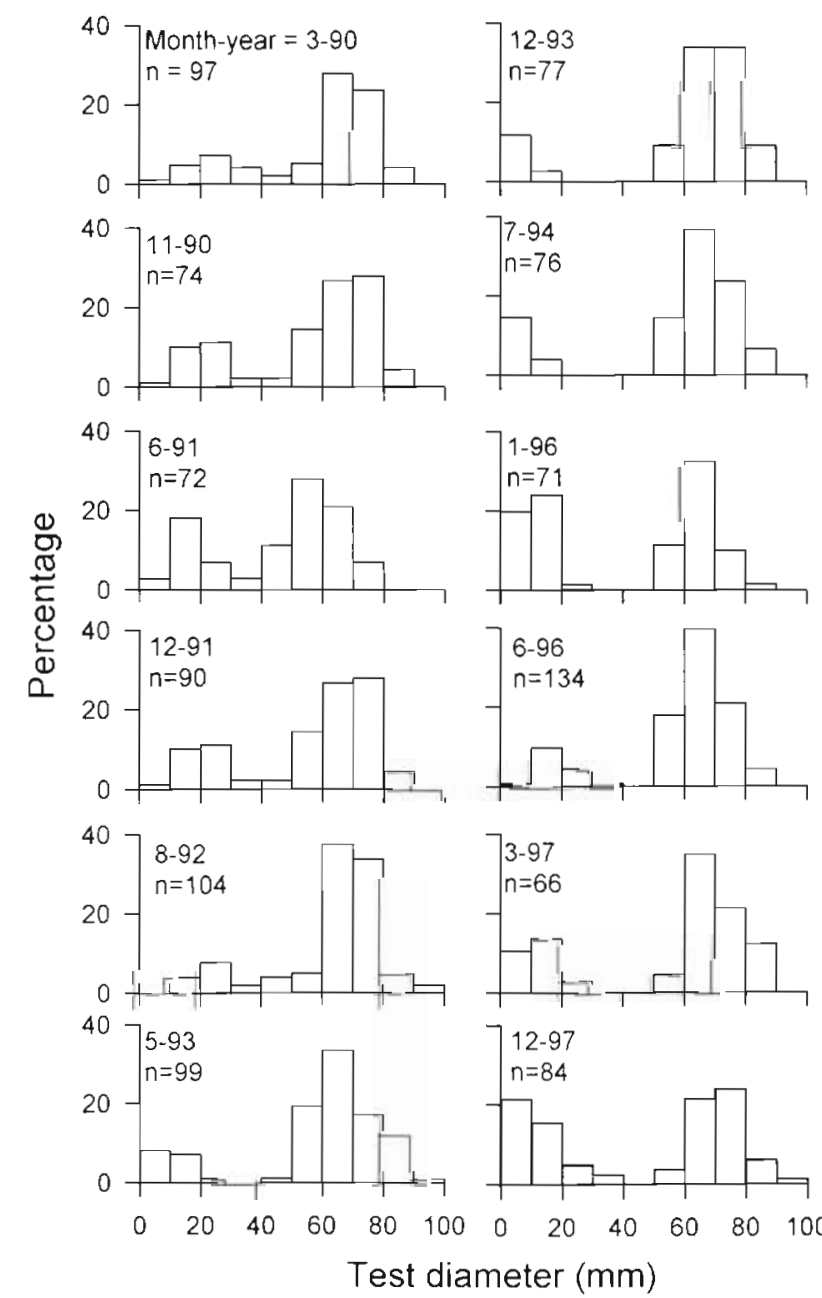

Fig. 6. Evechinus chloroticus. Population size structure at Waterfall Reef coralline flats, CROP Marine Reserve, 1990-1997 
Table 1. Evechinus chloroticus. Morphological characteristics of sea urchins at protected and fished sites at Leigh. Values are mean (SE), $\mathrm{n}=10 \mathrm{E}$. chloroticus per site. Sea urchins of 55 to $65 \mathrm{~mm}$ test diameter were used for the comparison, but due to low abundances of that cohort at Tower Rock, some larger individuals were used there. The lowest 2 rows give the mean (SE) pooled across all individuals from all sites within each level of protection. All values to 1 decimal place

\begin{tabular}{|lcc|}
\hline Site & $\begin{array}{c}\text { Test weight } \\
(\mathrm{g})\end{array}$ & $\begin{array}{c}\text { Pyramid length } \\
(\mathrm{mm})\end{array}$ \\
\hline $\begin{array}{l}\text { Marine Reserve } \\
\text { Waterfall }\end{array}$ & $48.3(1.6)$ & $15.7(0.1)$ \\
Tower Rock & $64.0(1.5)$ & $15.3(0.1)$ \\
Tabletop & $54.1(2.0)$ & $15.1(0.2)$ \\
Onespot & $52.6(2.4)$ & $13.9(0.1)$ \\
Rodney Cove & $49.6(1.0)$ & $15.2(0.1)$ \\
Coastal Leigh & & \\
Rodney South & $43.8(1.3)$ & $15.0(1.0)$ \\
Drift Bay & $41.8(1.3)$ & $15.0(0.1)$ \\
Vee Bay & $35.5(1.3)$ & $14.2(0.1)$ \\
Nordic Bay & $38.1(0.8)$ & $14.6(0.2)$ \\
Penguin St. & $40.9(1.5)$ & $14.5(0.1)$ \\
Protected & $53.7(1.1)$ & $15.0(0.1)$ \\
Fished & $40.0(0.7)$ & $14.7(0.1)$ \\
\hline
\end{tabular}

\section{Sea urchin transplants}

A critical assumption in the transplants was that migration to and from the plots did not unduly influence results. The degree of dispersal of Evechinus chloroticus from the central $16 \mathrm{~m}^{2}$ plot varied among trials at each site. However, very few sea urchins of transplant size were ever seen beyond the $36 \mathrm{~m}^{2}$ area so abundance in this Iarger plot was used for the analysis of the experiment.

At all sampling times, mean abundance of transplanted small Evechinus chloroticus in plots was lower at protected than at fished (control) sites, and in both Waterfall Reef (Reserve) trials (Fig. $7 \mathrm{~A}$ ) and at Tower Rock (Reserve) (Fig. 7B), mean abundance of transplants consistently declined through time. Numbers at the Onespot (Reserve) site (Fig. 7C) fluctuated conspicuously among samples, probably because diver observations were hindered there by rough weather on some sampling dates. Abundances of $E$. chloroticus in control plots generally remained high, with $>80 \%$ remaining in any one plot at the conclusion of the experiment. The magnitude and rate of decline was greatest at Waterfall Reef (Reserve), where means of $-13 \%$ (first trial) and $3 \%$ (second trial) of transplanted sea urchins remained in plots after 4 to 5 d (vs $95 \%$ for both controls). We were unable to directly attribute sea urchin disappearances to fish predation; no direct observations of predation were made and remote video observations of the plots at Waterfall Reef (Reserve) and Rodney South (fished)

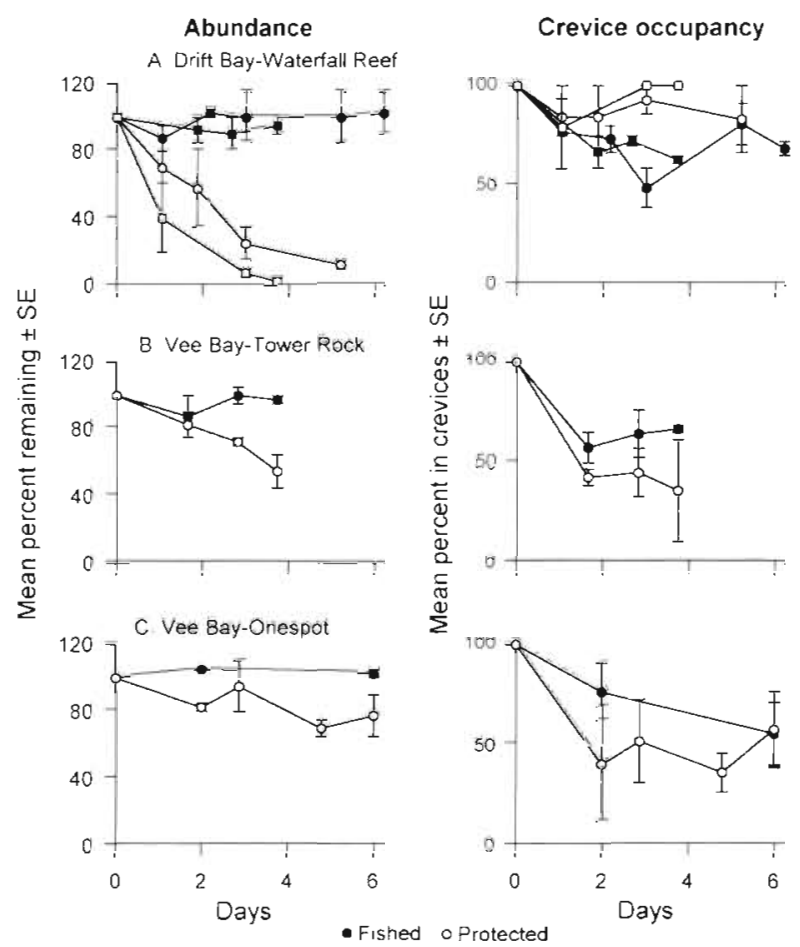

Fig. 7. Evechinus chloroticus. Abundance and crevice occupancy following transplants between fished and protected sites at Leigh. (A) Drift Bay to Waterfall Reef (Trial 1 = circles, Trial 2 =squares), (B) Vee Bay to Tower Rock, (C) Vee Bay to Onespot. Initial $n=20$. Open symbols: transplants from fished to protected sites; filled symbols: control transplants from fished back to fished sites

(1 daylight h per plot in second trial) also revealed no predatory strikes.

There was no clear trend in shelter occupancy of transplanted Evechinus chloroticus between protected and fished sites. For the Tower Rock (Reserve) and Onespot (Reserve) trials, crevice occupancy was lower at the reserve sites than at the control sites for almost all sampling dates (Onespot [Reserve] and Vee Bay [fished] values had converged by the last sample) (Fig. $7 \mathrm{~B}, \mathrm{C}$ ). In both Waterfall Reef (Reserve) trials, the opposite pattern occurred: shelter occupancy was greater on all sampling dates in plots at the reserve site (Fig. 7A).

\section{Fish density and size structure}

Carnivorous fishes were more abundant and larger on coralline flats in CROP Marine Reserve relative to Coastal Leigh (Fig. 8, Table 2). Pooled fish density was over 9 times greater in the protected area (Fig. 8A), and the differences were further emphasised when the 3 species (Parapercis colias, Pagrus auratus, and Cheilodactylus spectabilis) most likely to consume 

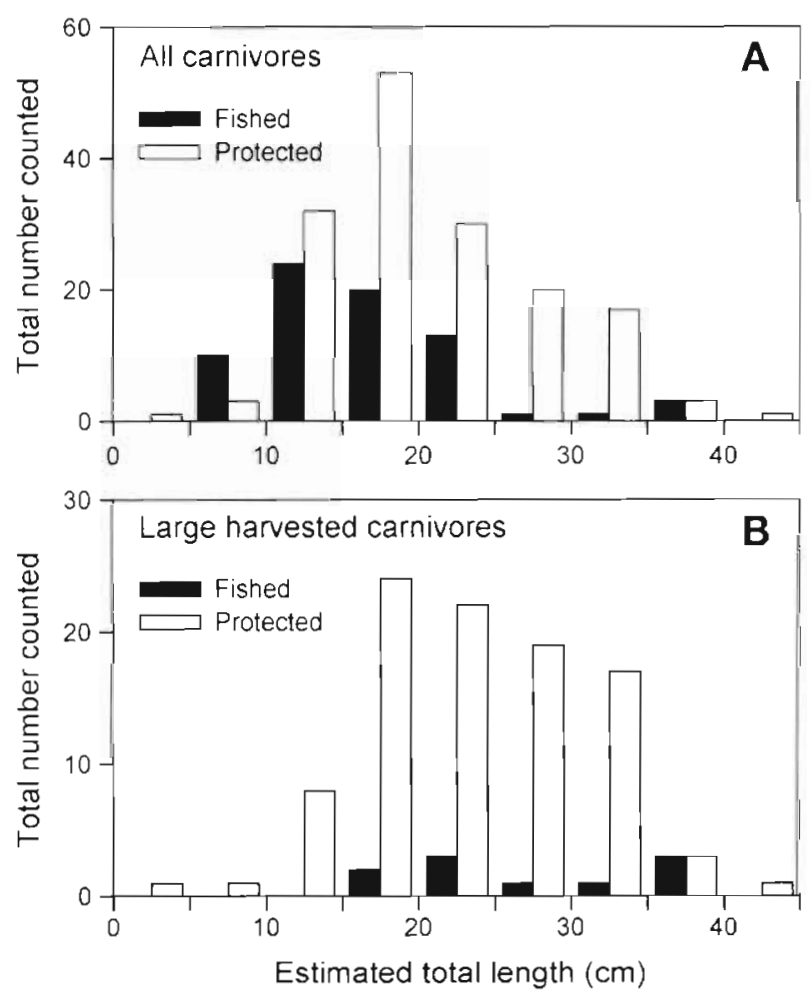

Fig. 8. Combined population size structure of (A) all carnivorous fishes and (B) combined Pagrus auratus, Parapercis colias and Cheilodactylus spectabilis derived from transect counts at CROP Marine Reserve and Coastal Leigh

small Evechinus chloroticus were considered as a group (Fig. 8B). Those 3 species were also more consistently present in the reserve than outside (Table 2), with only the monacanthid Parika scaber being slightly more abundant outside the reserve than inside.

\section{DISCUSSION}

The initial sea urchin population surveys suggested that variation in density, size structure and shelter occupancy of Evechinus chloroticus could not be solely attributed to the protection status of localities. Although all 3 MPAs in the survey have been protected from exploitation for over $10 \mathrm{yr}$, there are a number of important differences among them. Anecdotal evidence suggests that Tawharanui Marine Park, administered by a different authority to the 2 marine reserves, has been illegally fished more than the nearby CROP Marine Reserve, possibly because of the latter's higher public and scientific profile (S. Kelly pers. comm.). Probably for this reason, abundances of exploited fishes (T. J. Willis unpubl. data) and spiny lobsters (S. Kelly unpubl. data) appear to be much lower at Tawharanui than at Leigh. The 2 offshore island groups share a fish fauna distinct from coastal northeastern New Zealand by virtue of their position in the path of the East Auckland current (Choat \& Ayling 1987, Choat et al. 1988). That fauna comprises mainly large labrids which are not exploited, and size structures of fishes suggest that the Mokohinau Is. may have more large (>300 mm) fish than the Poor Krights Is. (Fig. 3 of Choat \& Ayling 1987). A direct effect of E. chloroticus harvesting at exploited sites is unlikely. Harvesting is of low intensity and predominantly targets intertidal/shallow subtidal populations (Mead 1996).

The strong contrast in population densities, size structures and shelter occupancies between the protected and fished Leigh localities was initially suggestive of a 'reserve effect'. Three lines of evidence consistent with direct and indirect effects of reserve

Table 2. Densities of carnivorous fishes for protected and fished sites at Leigh. Mean (SE) densities of 8 potential carnivores in $25 \times 5 \mathrm{~m}(\mathrm{n}=10)$ transect counts at each site. The lowest 2 rows give the mean (SE) pooled across all urchins from all sites within each level of protection. -: not present; all values to 1 decimal place

\begin{tabular}{|c|c|c|c|c|c|c|c|c|}
\hline Site & $\begin{array}{c}\text { Parapercis } \\
\text { colias }\end{array}$ & $\begin{array}{l}\text { Pagrus } \\
\text { auratus }\end{array}$ & $\begin{array}{c}\text { Cheilodactylus } \\
\text { spectabilis }\end{array}$ & $\begin{array}{l}\text { Upeneichtilys } \\
\text { lineatus }\end{array}$ & $\begin{array}{l}\text { Notolabrus } \\
\text { celidotus }\end{array}$ & $\begin{array}{l}\text { Parika } \\
\text { scaber }\end{array}$ & $\begin{array}{l}\text { Chironemus } \\
\text { marmoratus }\end{array}$ & $\begin{array}{l}\text { Notolabrus } \\
\text { fucicola }\end{array}$ \\
\hline \multicolumn{9}{|l|}{ Marine Reserve } \\
\hline Waterfall & $0.4(0.2)$ & $2.4(0.7)$ & $0.2(0.1)$ & $2.2(0.9)$ & $0.6(0.2)$ & $0.1(0.1)$ & - & - \\
\hline Tower & $0.3(0.2)$ & $0.2(0.2)$ & $0.5(0.3)$ & $0.2(0.1)$ & $0.6(0.2)$ & - & -- & - \\
\hline Tabletop & $1.0(0.4)$ & $0.3(0.2)$ & $0.5(0.2)$ & $0.2(0.1)$ & $0.6(0.2)$ & - & -- & - \\
\hline Onespot & - & $0.9(0.2)$ & $2.1(0.5)$ & $0.6(0.3)$ & $0.5(0.2)$ & - & - & - \\
\hline Rodney Cove & $0.7(0.3)$ & $0.1(0.1)$ & - & $0.6(0.3)$ & $0.2(0.1)$ & - & - & - \\
\hline \multicolumn{9}{|l|}{ Coastal Leigh } \\
\hline Rodney South & - & - & $0.4(0.2)$ & - & $0.4(0.2)$ & $0.3(0.2)$ & $0.1(0.1)$ & $0.1(0.1)$ \\
\hline Drift Bay & $0.2(0.1)$ & - & - & $0.1(0.1)$ & $0.2(0.1)$ & - & - & - \\
\hline Vee Bay & $0.1(0.1)$ & $0.1(0.1)$ & $0.1(0.1)$ & $1.0(0.3)$ & - & - & - & - \\
\hline Nordic Bay & - & - & - & $1.9(1.2)$ & $0.4(0.2)$ & - & - & - \\
\hline Penguin St. & - & $0.1(0.1)$ & - & $1.2(0.8)$ & $0.4(0.2)$ & - & $0.1(0.1)$ & - \\
\hline Protected & $0.5(0.1)$ & $0.8(0.2)$ & $0.7(0.2)$ & $0.8(0.2)$ & $0.5(0.1)$ & $0.0(0.0)$ & - & - \\
\hline Fished & $0.1(0.0)$ & $0.0(0.0)$ & $0.1(0.0)$ & $0.8(0.3)$ & $0.3(0.1)$ & $0.1(0.0)$ & $0.0(0.0)$ & $0.0(0.0)$ \\
\hline
\end{tabular}


protection derive from Leigh studies. First, predatory fish densities appeared to be higher in the reserve (McCormick \& Choat 1987, Cole et al. 1990, this study). Second, over the last $10 \mathrm{yr}$ the density of Evechinus chloroticus has declined at several sites in the reserve (Cole 1993). Third, substantial changes in habitat distribution, particularly decreases in the extent of urchin-dominated coralline flats, have occurred (Cole 1993, Shears \& Babcock unpubl. data, R. Cole pers. obs.). Although the exploited area, Coastal Leigh, has not been as intensively studied as CROP Marine Reserve, extensive coralline flats existed at all sites examined, and have done so since at least 1992 (Shears \& Babcock unpubl. data, authors' pers. obs.).

One consistent trend that emerged from the population survey was the more bimodal nature of Evechinus chloroticus size structures from protected localities. The integration of recruitment, growth and mortality into sea urchin population size structures limits speculation on the causes of this variation, particularly from point samples (Ebert et al. 1993). As E. chloroticus growth is slow and variable (Walker 1981, Andrew \& Choat 1985 , Kerrigan 1987), and individuals can live for at least 10 yr (Walker 1977), neither mode in bimodal size structures represents a single year class. The long-term information from Waterfall Reef clearly showed regular recruitment to a stable, strongly bimodal size distribution, indicative of size-specific rates of growth or mortality (Ebert et al. 1993). E. chloroticus size distributions at other CROP Marine Reserve sites sampled in previous years have similarly been bimodal (Kerrigan 1987. Cole 1993), whereas previous samples of size structure from Coastal Leigh have been almost universally unimodal (Cole 1993). (Andrew \& Choat 1982 presented evidence for stable bimodality in E. chloroticus size distributions at Waterfall Reef soon after the reserve was established; however, the temporal variability among those distributions was not seen in this study).

There are 2 non-mutually exclusive explanations for the low representation of the 30 to $50 \mathrm{~mm}$ group in the populations at Leigh. The trough between modes may result from accelerated growth, if greater access to macroalgal food occurs when the crevice-dwelling habit is abandoned (e.g Himmelman 1986). The influence of growth on population size structures is speculative in the absence of size-specific age or growth data. Estimating long-term growth rates of Evechinus chloroticus of a range of sizes with tetracycline markrecapture would be profitable (cf. McShane \& Anderson 1997), but the large sample sizes that would need to be marked (and later destroyed) would conflict with the reserve status of the best-studied localities.

The data of Walker (1981) suggest that Evechinus chloroticus of $30 \mathrm{~mm}$ TD are 2 yr old, with subsequent year classes being 40,50 and 55 to $60 \mathrm{~mm}$ TD. These size-age data do not suggest that the trough in the size frequency distributions is due to enhanced growth. A remarkable acceleration of growth rate (cf. Andrew \& Choat 1985) would be necessary to 'speed' individuals through $30 \mathrm{~mm}$ of test growth (30 to $60 \mathrm{~mm}$ ) without being detected in samples. Levitan (1992) found relatively larger lanterns in food-deprived echinoids. In regressions of log lantern weight on log total weight for $E$. chloroticus from coralline flats and vegetated habitats, Cole (1993) found a higher intercept value for the coralline flats, as expected from similar studies elsewhere (review of Ebert 1996). Thus the absence of differences in relative jaw size between reserve and Coastal Leigh sites in our study is not consistent with more rapid growth in the protected area. Our transplant experiment suggests that size-specific variation in mortality is a more likely explanation than growth for the trough in the size structures.

Evechinus chloroticus' morphometric parameters also varied between reserve and fished sites. Variation in test morphology among sea urchin populations or species has previously been attributed to variation in wave exposure (e.g. Dix 1970a, Lewis \& Storey 1984, Drummond 1993, 1994, McShane \& Anderson 1997). However, the protected and fished coasts of Leigh have similar aspects and are exposed to storms from similar quarters (predominantly the northeast) (e.g. McCormick \& Choat 1987). Selective mortality of juvenile $E$. chloroticus with thin tests via predation or increased calcification induced by sublethal attacks (Edwards \& Ebert 1991) could produce the greater test weights in CROP Marine Reserve.

The implication from our study is that higher abundances of predators within CROP Marine Reserve are the causal agent of bimodal size frequency distributions. Bimodality of sea urchin population size structures is most frequently linked to predation (e.g. Tegner \& Dayton 1981, Andrew \& Choat 1982, Tegner \& Levin 1983, Scheibling \& Stephenson 1984, Himmelman 1986. Scheibling \& Raymond 1990, Andrew \& MacDiarmid 1991, Ojeda \& Dearborn 1991). The most likely predators of small sea urchins are the fishes we found to be more abundant and larger in the marine reserve. The size range of Evechinus chloroticus which may be consumed by fishes is unknown, although remains of individuals $>30 \mathrm{~mm}$ have been found in the guts of Pagrus auratus caught at Goat Island (T. Willis pers. obs.). Further, we believe that the fish count data underestimate the abundance of the largest $P$. auratus, which swim in midwater, and thus were not sampled by benthic transects. The suggestion that fish predators influence population size structure of E. chloroticus populations at Leigh localities is supported by the results of the sea urchin transplants and the contrasting patterns of shelter occupancy between localities. The 
rapid loss of individuals, particularly at Waterfall Reef, strongly suggests that exposed 30 to $40 \mathrm{~mm}$ TD sea urchins are vulnerable to predation. The smaller losses that occurred over 4 to $5 \mathrm{~d}$ at Tower Rock and Onespot are still significant if integrated over longer time scales. Spiny lobsters are uncommon on coralline flats (Andrew \& Choat 1982, Andrew \& MacDiarmid 1991) and while the influences of crabs, starfish and octopus are unknown, they are not conspicuous in the habitat (Andrew \& Choat 1982, authors' pers, obs.).

Small echinoids commonly occupy cryptic microhabitats (e.g. Tegner \& Dayton 1977, Bernstein et al. 1981, Tegner \& Levin 1983, Scheibling \& Raymond 1990), and increased predation on abandonment of refuge is inferred to produce bimodality (e.g. Andrew \& MacDiarmid 1991, Scheibling \& Hamm 1991). We are uncertain to what degree attrition and learning contribute to the persistence of 20 to $50 \mathrm{~mm}$ TD Evechinus chloroticus in crevices within the marine reserve. If $E$. chloroticus in CROP Marine Reserve emerge from crevices at the same size as those at Coastal Leigh, individuals in the 20 to $50 \mathrm{~mm}$ size range could be restricted to crevices by direct mortality of exposed individuals or a behavioural response to (1) the presence of predators (e.g. Bernstein et al. 1981, Tegner \& Levin 1983, Vadas et al. 1986, Scheibling \& Hamm 1991), (2) sublethal predation (e.g. Carpenter 1984), or (3) damaged conspecifics (Mann et al. 1984, Parker \& Shulman 1986). Data from Tutukaka (R. Cole unpubl. data) and observations at several other sites (e.g. Whangarei Heads) (see Fig. 1 for locations) suggest that emergence of $E$. chloroticus from crevices at small sizes is a widespread feature of unprotected areas in northeastern New Zealand. By recording crevice occupancy in the transplant experiments we aimed to address differences in behaviour, but the results were inconclusive due to the short duration of the experiments, and may have been influenced by handling effects.

Andrew \& Choat (1982) excluded predators from small areas of coralline flats at Waterfall Reef 4 yr after protection was established and found that Evechinus chloroticus $<30 \mathrm{~mm}$ TD were more abundant in cages than in uncaged areas. While they considered this to be evidence for a predation effect, they concluded that predation was insufficient to reduce urchin densities or eliminate the coralline flats habitat. Like Andrew \& Choat (1982) we have no conclusive evidence that predation by fishes is responsible for the decline in abundances seen in this study. Present densities of predators at Leigh may be sufficient to alter densities, size structures and microhabitat distribution of E. chloroticus. Nevertheless, events at the habitat level are equivocal; losses of coralline flats habitat in CROP Marine Reserve have not been confined to areas where fish predators are most abundant (Cole 1993, 1994) and Waterfall Reef has high densities of those fishes but remains as coralline flats. The intensity of $E$. chloroticus recruitment to Waterfall Reef may be the reason for the persistence of intensely grazed habitat despite severe predation pressure; Keuskamp (1997) suggested higher settlement occurred there than at other reserve sites.

The use of MPAs to study predation effects directly is a relatively recent development. Sala \& Zabala (1996) and Sala (1997) examined mortality of a sea urchin in areas of varying fish abundance. Those studies found lower survival of tethered sea urchins at sites with high fish densities, though in both studies artifacts (of tethering and diver responsiveness respectively) may have confounded the experiment. This approach has also been used in Kenya (e.g. McClanahan \& Muthiga 1989), where there is strong evidence that predation by fishes has a cascading influence on coral reef community structure (McClanahan et al. 1996). Such trophic cascades, while relatively well-known in freshwater habitats (e.g. Wooster 1994, McIntosh \& Townsend 1996) appear to be less common in the marine environment. In a recent review, Menge (1997) found that indirect effects emerged as rapidly as direct ones in rocky intertidal systems (e.g. Wootton 1995). Jones et al. (1993) reviewed the evidence for trophic cascades from marine protected areas, and suggested that long-term studies would be required. Unfortunately, habitat-level differences between protected and fished areas at Leigh are only being documented now, 20 yr after the reserve was established (Shears \& Babcock unpubl. data).

Further ecological research in northeastern New Zealand needs to be undertaken outside marine reserves. There is already concern about the limited geographic range from which experiments have been done, and the dangers of extrapolating from reserve studies to other areas (Cole 1993). While reserves offer numerous advantages for researchers (Creese \& Jeffs 1993), studies in reserves may not be relevant for management of non-reserve areas. Numerous marine reserves have been created by the New Zealand Government's Department of Conservation (see Table 2 of Creese \& Cole 1995), giving an opportunity to assess both the direct effects of harvesting, and the generality of the cascading effects described here. These reserves could function as predator addition experiments at large spatial scales, provided adequate data are collected to document changes in population abundances, sizes and habitat distributions. Studies in marine protected areas can go beyond Hutchings' (1996, p. 960) 'dominant question': 'What are the effects of fishing on the behaviour, life history, and population biology of exploited fishes?' to address ecosystem level effects of human harvesting. 
Acknowledgements. Thanks to all those who helped in the field. B. Doak, M. Kampman and A. Thomas skippered RV 'Proteus' to offshore localities and T Crocker helped in the laboratory. F. J. Brook and NZ Department of Conservation, Whangarei assisted with access to the Poor Knights Is. R. Davidson and P. McShane provided helpful discussions, and useful comments on versions of the manuscript were given by D. Keats, D. Schel, C. Syms, and R. Taylor.

\section{LITERATURE CITED}

Andrew NL (1988) Ecological aspects of the common sea urchin, Evechinus chloroticus, in northeastern New Zealand: a review. N Z J Mar Freshwat Res 22:415-426

Andrew NL, Choat JH (1982) The influence of predation and conspecific adults on the abundance of juvenile Evechinus chloroticus (Echinoidea: Echinometridae). Oecologia 54: $80-87$

Andrew NL, Choat JH (1985) Habitat related differences in the growth and survivorship of juvenile echinoids. Mar Ecol Prog Ser 27:155-161

Andrew NL, MacDiarmid AB (1991) Interrelations between sea urchins and spiny lobsters in northeastern New Zealand. Mar Ecol Prog Ser 70:21.1-222

Andrew NL, Stocker LJ (1986) Dispersion and phagokinesis in the echinoid Evechinus chloroticus (Val.). J Exp Mar Biol Ecol 100:11-23

Aronson RB (1990) Onshore-offshore patterns of human fishing activity. Palaios 5:88-93

Ayling AM (1978) Cape Rodney to Okakari Point Marine Reserve: a biological survey. University of Auckland Leigh Marine Laboratory Bulletin 1

Ayling AM (1981) The role of biological disturbance in temperate subtidal encrusting communities. Ecology 62 $830-847$

Ballantine WJ (1991) Marine reserves for New Zealand. University of Auckland Leigh Laboratory Bulletin 25

Bernstein BB, Schroeter SC, Mann KH (1983) Sea urchin (Strongylocentrotus droebachiensis) aggregating behavjour investigated by means of a subtidal multifactorial experiment. Can J Fish Aquat Sci 40:1975-1986

Bernstein BB, Williams BE, Mann $\mathrm{KH}$ (1981) The role of behavioural responses to predators in modifying urchins' (Strongylocentrotus droebachiensis) destructive grazing and seasonal foraging patterns. Mar Biol 63:39-49

Black R, Johnson MS, Trendall JT (1982) Relative size of Aristotle's lantern in Echinometra mathaei occurring at different densities. Mar Biol 71:101-106

Breen PA, Carson TA, Foster JB, Stewart TA (1982) Changes in subtidal community structure associated with British Columbia sea otter transplants. Mar Ecol Prog Ser 7:13-20

Breen PA, Mann KH (1976) Changing lobster abundance and the destruction of kelp beds by sea urchins. Mar Biol 34: $137-142$

Carpenter RC (1984) Predator and population density control of homing behaviour in the Caribbean echinoid Diadema antillarum. Mar Biol 82:101-108

Choat JH, Ayling AM (1987) The relationship between habitat structure and fish faunas on New Zealand reefs. J Exp Mar Biol Ecol 110:257-284

Choat JH, Aylinc AM, Schiel DR (1988) Temporal and spatial variation in an island fish fauna. J Exp Mar Biol Ecol 121: $91-111$

Choat JH, Schiel DR (1982) Patterns of distribution and abundance of large brown algae and invertebrate herbivores in subtidal regions of northern New Zealand. J Exp Mar Biol
Ecol 60:129-162

Cole RG (1993) Distributional relationships among subtidal algae, sea urchins and reef fish in northeastern New Zealand. PhD thesis, University of Auckland

Cole RG (1994) Abundance, size structure, and diver-oriented behaviour of three large benthic carnivorous fishes in a marine reserve in northeastern New Zealand. Biol Conserv 70:93-99

Cole RG, Ayling AM, Creese RG (1990) Effects of marine reserve protection at Goat Island, northern New Zealand. N Z J Mar Freshwat Res 24:197-210

Constable AJ (1993) The role of sutures in shrinking of the test in Heliocidaris erythrogramma (Echinoldea: Echinometridae). Mar Biol 117:423-430

Cowen RK, Agegian CR, Foster MS (1982) The maintenance of community structure in a central California giant kelp forest. J Exp Mar Biol Ecol 64:189-201

Creese RG, Cole RG (1995) Marine conservation in New Zealand. Pac Conserv Biol 2:55-63

Creese RG, Jeffs A (1993) Biological research in New Zealand marine reserves. In: Battershill CN, Schiel DR, Jones GP, Creese RG, MacDiarmid AB (eds) Proceedings of the Second International Temperate Reef Symposium. NIWA Marine, Wellington, p 15-22

Dean TA, Schroeter SC, Dixon JD (1984) Effects of grazing by two species of sea urchins (Strongylocentrotus franciscanus and Lytechinus anamesus) on recruitment and survival of two species of kelp (Macrocystis pyrifera and Pterygophora californica). Mar Biol 78:301-313

Dix TG (1970a) Biology of Evechinus chloroticus (Echinoidea: Echinometridae) from different localities. 1. General. N Z J Mar Freshwat Res 4:91-116

Dix TG (1970b) Biology of Evechinus chloroticus (Echinoidea: Echinometridae) from different localities. 2. Movement. N Z J Mar Freshwat Res 4:267-277

Drummond AE (1993) Exposure to wave action: some consequences for the sea urchin Stomopneustes vulgaris on the Natal coast S Afr J Zool 28:198-201

Drummond AE (1994) Aspects of the life history biology of three species of sea urchin on the South African east coast. In: David B, Guille A, Féral JP, Roux M (eds) Echinoderms through time. AA Balkema, Rotterdam, p 637-641

Ebeling AW, Laur DR, Rowley RJ (1985) Severe storm disturbances and reversal of community structure in a southern California kelp forest. Mar Biol 84:287-294

Ebert TA (1980) Relative growth of sea urchin jaws: an example of plastic resource allocation. Bull Mar Sci 30 : $467-4.74$

Ebert TA (1996) Adaptive aspects of phenotypic plasticity in echinoderms. Oceanol Acta 19:347-355

Ebert TA, Schroeter SC, Dixon JD (1993) Inferring demographic processes from size-frequency distributions: effect of pulsed recruitment on simple models. Fish Bull (Wash DC) $91: 237-243$

Ebling FJ, Hawkins AD, Kitching JA, Muntz L, Pratt VM (1966) The ecology of Lough Ine. XVI. Predation and nocturnal migration in the Paracentrotus community. J Anim Ecol 35:559-566

Edwards PB, Ebert TA (1991) Plastic responses to limited food availability and spine damage in the sea urchin Strongylocentrotus purpuratus (Stimpson). J Exp Mar Biol Ecol 145 $205-220$

Elner RW, Vadas RL (1990) Inference in ecology: the sea urchin phenomenon in the northwestern Atlantic. Am Nat 136:108-125

Estes JA (1995) Top-level carnivores and ecosystem effects: questions and approaches. In: Jones CG, Lawton JH (eds) 
Linking species and ecosystems. Chapman \& Hall, New York, p 151-158

Estes JA, Duggins DO (1995) Sea otters and kelp forests in Alaska: generality and variation in a community ecological paradigm. Ecol Monogr 65:75-100

Estes JA, Smith NS, Palmisano JF (1978) Sea otter predation and community organization in the western Aleutian Islands, Alaska. Ecology 59:822-833

Foreman RE (1977) Benthic community modification and recovery following intensive grazing by Strongylocentrotus droebachiensis. Helgol Wiss Meeresunters 30:468-484

Foster MS, Schiel DR (1988) Kelp communities and sea otters: keystone species or just another brick in the wall? In: Van Blaricom GR, Estes JA (eds) The community ecology of sea otters. Springer-Verlag, Berlin, p 92-115

Harris LG, Ebeling AW, Laur DR, Rowley RJ (1984) Community recovery after storm damage: a case of facilitation in primary succession. Science 224:1336-1338

Harrold C, Pearse JS (1987) The ecological role of echinoderms in kelp forests. Echinoderm Stud 2:137-233

Harrold C, Reed DC (1985) Food availability, sea urchin grazing, and kelp forest community structure. Ecology 66 : $1160-1169$

Himmelman JH (1986) Population biology of green sea urchins on rocky barrens. Mar Ecol Prog Ser 33:295-306

Hutchings JA (1996) Spatial and temporal variability in the density of northern cod and a review of hypotheses for the stock's collapse. Can J Fish Aquat Sci 53:943-962

Jones GP, Cole RG, Battershill CN (1992) Marine reserves: do they work? In: Battershill CN, Schiel DR, Jones GP, Creese RG, MacDiarmid AB (eds) Proceedings of the Second International Temperate Reef Symposium. NIWA Marine, Wellington, p 29-45

Kerrigan BA (1987) Abundance patterns of intertidal and subtidal populations of Evechinus chloroticus. MSc thesis, University of Auckland

Keuskamp D (1997) Recruitment and population dynamics of Evechinus chloroticus. MSc thesis, University of Auckland, New Zealand

Lawrence JM (1975) On the relationships between marine plants and sea urchins. Oceanogr Mar Biol Annu Rev 13: $213-286$

Lawrence JM (1996) Mass mortality of echinoderms from abiotic factors. Echinoderm Stud 5:103-137

Lawrence JM, Sammarco P (1982) Effects of feeding on the environment: Echinoidea. In: Jangoux M, Lawrence JM (eds) Echinoderm nutrition. AA Balkema, Rotterdam, p 499-519

Levitan DR (1991) Skeletal changes in the test and jaws of the sea urchin Diadema antillarum in response to food limitation. Mar Biol 111:431-435

Levitan DR (1992) Community structure in times past: influence of human fishing pressure on algal-urchin interactions. Ecology 73:1597-1605

Lewis JB, Storey GS (1984) Differences in morphology and life history traits of the echinoid Echinometra lucunter from different habitats. Mar Ecol Prog Ser 15:207-211

Mann KH (1982) Kelp, sea urchins and predators: a review of strong interactions in rocky subtidal systems of eastern Canada, 1970-1980. Neth J Sea Res 16: 414-423

Mann KH, Wright JLC, Welsford BE, Hattfield E (1984) Responses of the sea urchin Strongylocentrotus droebachiensis (O. F. Muller) to water-borne stimuli from potential predators and potential food algae. J Exp Mar Biol Ecol 79:233-244

MacDiarmid AB (1991) Seasonal changes in depth distribution, sex ratio and size frequency of spiny lobster Jasus edwardsii on a coastal reef in northern New Zealand. Mar
Ecol Prog Ser 70:129-141

MacDiarmid AB, Breen PA (1993) Spiny lobster population change in a marine reserve. In: Battershill CN, Schiel DR, Jones GP, Creese RG, MacDiarmid AB (eds) Proceedings of the Second International Temperate Reef Symposium. NIWA Marine, Wellington, p 47-56

McClanahan TR, Kamukuru AT, Muthiga NA, Yebio MG, Obura D (1996) Effect of sea urchin reductions on algae, coral, and fish populations. Conserv Biol 10:136-154

McClanahan TR, Muthiga NA (1989) Patterns of predation on a sea urchin, Echinometra mathaei (de Blainville), on Kenyan coral reefs. J Exp Mar Biol Ecol 126:77-94

McCormick MI, Choat JH (1987) Estimating total abundance of a large temperate reef fish using visual strip transects. Mar Biol 96:469-478

McIntosh AR, Townsend CR (1996) Interactions between fish, grazing invertebrates and algae in a New Zealand stream: a trophic cascade mediated by fish-induced changes to grazer behaviour? Oecologia 108:174-181

McShane PE, Anderson OF (1997) Resource allocation and growth rates in the sea urchin Evechinus chloroticus (Echinoidea: Echinometridae). Mar Biol 128: 657-663

Mead ST (1996) Fertilization success, sustainable management and commercial development of the New Zealand sea urchin, Evechinus chloroticus. MSc thesis, University of Auckland

Menge BA (1997) Detection of direct versus indirect effects: were experiments long enough? Am Nat 149:801-823

Miller RJ (1985) Seaweeds, sea urchins, and lobsters: a reappraisal. Can J Fish Aquat Sci 42:2061-2072

Ojeda FP, Dearborn JH (1991) Feeding ecology of benthic mobile predators: experimental analyses of. their influences in rocky subtidal communities in the Gulf of Maine. J Exp Mar Biol Ecol 149:13-44

Parker DA, Shulman MJ (1986) Avoiding predation: alarm responses of Caribbean sea urchins to simulated predation on conspecific and heterospecific sea urchins. Mar Biol 93:201-208

Sala E (1997) Fish predators and scavengers of the sea urchin Paracentrotus lividus in protected areas of the north-west Mediterranean Sea. Mar Biol 129:531-539

Sala E, Zabala M (1996) Fish predation and the structure of the sea urchin Paracentrotus lividus populations in the NW Mediterranean. Mar Ecol Prog Ser 140:71-81

Scheibling RE (1996) The role of predators in regulating sea urchin populations in eastern Canada. Oceanol Acta 19: $421-430$

Scheibling RE, Hamm J (1991) Interactions between sea urchins (Strongylocentrotus droebachiensis) and their predators in field and laboratory experiments. Mar Biol 110: $105-116$

Scheibling RE, Raymond BG (1990) Community dynamics on a subtidal cobble bed following mass mortalities of sea urchins. Mar Ecol Prog Ser 63:127-145

Scheibling RE, Stephenson RL (1984) Mass mortalities of Strongylocentrotus droebachiensis (Echinodermata: Echinoidea) off Nova Scotia, Canada. Mar Biol 78:153-164

Schiel DR (1982) Selective feeding by the echinoid, Evechinus chloroticus, and the removal of plants from subtidal algal stands in northern New Zealand. Oecologia 54:379-388

Schiel DR, Foster MS (1986) The structure of subtidal algal stands in temperate waters. Oceanogr Mar Biol Annu Rev 24:265-307

Tegner MJ, Dayton PK (1977) Sea urchin recruitment patterns and implications of commercial fishing. Science 196 : $324-326$

Tegner MJ, Dayton PK (1981) Population structure, recruit- 
ment, and mortality of two sea urchins (Strongylocentrotus franciscanus and $S$. purpuratus) in a kelp forest. Mar Ecol Prog Ser 5:255-268

Tegner MJ, Levin LA (1983) Spiny lobsters and sea urchins: analysis of a predator-prey interaction. J Exp Mar Biol Ecol 73:125-150

Vadas RL, Elner RW, Garwood PE, Babb IG (1986) Experimental evaluation of aggregation behaviour in the sea urchin Strongylocentrotus droebachiensis: a reinterpretation. Mar Biol 90:433-448

Editorial responsibility: Otto Kinne (Editor),

Oldendorf/Luhe, Germany
Walker MM (1977) Local variation in the population biology of Evechinus chloroticus (Valenciennes). MSc thesis, University of Auckland

Walker MM (1981) Influence of season on growth of the sea urchin Evechinus chloroticus. N Z J Mar Freshwat Res 15: 201-205

Wooster D (1994) Predator impacts on stream benthic prey. Oecologia 99:7-15

Wootton JT (1995) Effects of birds on sea urchins and algae: a lower-intertidal trophic cascade. Ecoscience 2:321-328

Submitted: March 31, 1998; Accepted: July 31, 1998

Proofs received from author(s): October 26, 1998 